\title{
Investigation Report on Human Resource Allocation under Low Carbon Economy
}

\author{
Xiaoli Liu \\ Sichuan University of Science and Engineering, Zigong 643000, China
}

\begin{abstract}
Keywords: low carbon economy; human resource allocation; industrial structure; employment structure
\end{abstract}

\begin{abstract}
Low-carbon development mode has become a new rule of world economic development pattern. This report surveys industrial structure and employment structure of Sichuan Province from the perspective of macroscopic human resource allocation, and analyzes problems and countermeasures of optimizing human resource allocation under low carbon economy in order to provide reference for related departments to formulate relevant policies.
\end{abstract}

Low carbon economy refers to a new economic mode based on low energy consumption, low emission and low pollution. In 1900-2003, China's GDP growth accounted for about 10\% in the world; energy consumption rise occupied for about $25 \%$; the increase in greenhouse gas emotion accounted for $34 \%{ }^{[1]}$. The $4^{\text {th }}$ assessment report of IPCC predicts that $2 / 3-3 / 4$ of global future emotion growth may come from developing countries and the main emission reduction potential is also in developing countries. It is more economical and feasible to tale emotion reduction measures earlier ${ }^{[2]}$. The development of low carbon economy has become an inevitable choice of China to achieve sustainable development. The development of low carbon economy will certainly trigger readjustment of industrial distribution and changes of industrial structure. Industrial structure and employment structure are mutually influenced. On this account, the members of this research group utilized the opportunity of development of low carbon economy and made a survey of human resource allocation under low carbon economy in Sichuan Province.

\section{Status analysis}

Sichuan Province destroyed some employment posts and changed skill requirements of some posts during carrying out low carbon economic mode. Meanwhile, some new posts were created. Local government takes low-carbon development mode and adheres to investment projects oriented to energy conservation and emission reduction. Thus, new employment posts about new energy development, energy conservation and cleaner production industry are created. Meanwhile, in the process of energy conservation, effect enhancement and technical equipment reform for traditional secondary industry, skill requirements of employment posts also change. Promotion of low carbon economic mode triggers structural adjustment of labor force market. Thus, labor force is allocated again in different industries and regions.

\subsection{Changes of industrial structure lead to variations of employment structure}

One of distinguishing features of development of low carbon economic mode is the change in industrial structure. As industrial structure alters, labor demand structure on the labor market will certainly change correspondingly. Table 2-1 and Table 2-2 show employment structure and labor productivity of three industries in Sichuan province. It can be seen that employees in the primary industry presents a declining trend; the secondary industry and the tertiary industry become the main force attracting employment. In other words, as energy conservation, emission reduction, effect enhancement and reform advance, energy conservation and emission reduction in key fields can be controlled well through eliminating laggard equipment and strictly controlling the projects with pollution and high energy consumption. The promotion of high and new technology creates an increasing number of green employment posts. The secondary industry actively transforms of energy conservation and effect enhancement and greatly improves labor productivity. The position 
of industrial structure alters. The position of the secondary industry and the tertiary industry rises with equal proportion. Labor force transfers to the secondary industry and the tertiary industry by a large scale. Through comparing Table 2-1 and Table 2-3, we can see compared with nationwide situations, the tertiary industry of Sichuan Province has large development space and can provide many employment posts. Of course, in the process of large-sale adjustment of industrial structure, negative effects should be avoided as far as possible in structural transition.

Table 2-1 practitioner ratio of three industries in Sichuan Province

\begin{tabular}{|c|l|l|l|l|} 
(the number of all employees is 100) & Unit: \% & \\
\hline & & & & \\
\hline The primary industry & & & & \\
\hline The secondary industry & & & & \\
\hline The tertiary industry & & & \\
\hline
\end{tabular}

Data source: 2012 Statistical Yearbook of Sichuan

Table 2-2 Labor productivity of three industries in Sichuan Province

\begin{tabular}{|c|l|l|l|l|}
\hline & & & \multicolumn{1}{|c|}{ Unit: Yuan/one } \\
\hline The primary industry & & & & \\
\hline The secondary industry & & & & \\
\hline The tertiary industry & & & & \\
\hline
\end{tabular}

Data source: 2012 Statistical Yearbook of Sichuan

Table 2-3 Nationwide employment structure of thre industries

\begin{tabular}{|l|l|l|l|}
\hline \multicolumn{1}{|c|}{ Year } & \multicolumn{1}{|l|}{} \\
\hline & & & \\
\hline 2008 & & & \\
\hline 2009 & & & \\
\hline 2010 & & & \\
\hline 2011 & & & \\
\hline
\end{tabular}

Data source: 2012 Statistical Yearbook of Chinese Labor Force

\subsection{The government promotes low carbon economy to drive growth of employment}

Local government energetically carries out "green employment" in clean energy, smart power grids and construction transformation. On the one hand, this can reduce environmental destruction caused by energy demand; on the other hand, this can enhance cultivation of "green employment" posts, relieve unemployment pressure arising from industrial structural adjustment and upgrade.[3]

The government promotes development of low carbon economy in such fields as industry, transportation industry, construction industry, public field and commerce, provides new employment posts for industries with low energy consumption and high output and creates emerging employment posts of green employment. As shown in Table 2-4, employment proportion of electric power, gas supply, water supply and pollution governance industry is low. As the development of low carbon economy, the two industries can provide great space for employment. Meanwhile, energy structure adjustment promotes industrial structure adjustment, which will inevitably trigger structure adjustment of labor market. This puts forward different requirements for the government to work out employment policy and for enterprises to improve human resource management level and for improvement of job seekers' ability.

Table 2-4 Nationwide labor force employment $\quad$ Unit: \%

\begin{tabular}{|c|l|l|l|l|}
\hline Industry structure of employees (\%) & & & \\
\hline $\begin{array}{c}\text { Agriculture, forestry, fishery and } \\
\text { animal husbandry }\end{array}$ & & & & \\
\hline Industry & & & & \\
\hline $\begin{array}{c}\text { Mining industry and extractive } \\
\text { industry }\end{array}$ & & & & \\
\hline Manufacturing industry & & & & \\
\hline Electric power and gas supply & & & \\
\hline
\end{tabular}




\begin{tabular}{|l|l|l|l|l|}
$\begin{array}{c}\text { Water supply and pollution } \\
\text { governance industry }\end{array}$ & & & & \\
\hline Construction industry & & & & \\
\hline Service industry & & & & \\
\hline
\end{tabular}

Data source: 2012 Statistical Yearbook of Chinese Labor Force

\section{Problems and causes}

Low carbon economic development mode of Sichuan province is the same with nationwide development mode. Great achievements have been gained in attention paid by the government, energy conservation, emission reduction and technological innovation. Meanwhile, some achievements are also gained in talent introduction and attraction enhancement. But, human resource allocation of Sichuan province has not reached the best state. The reasons include the following:

\subsection{Unbalanced regional economic development affects optimization of human resource allocation}

On a national scale, new technique, new energy and new material industries concentrate in eastern coastal developed regions, while most traditional industries concentrate in central and western regions. Such industrial distribution structure directly influences human resource allocation. Thus, the number of innovative talents in western area is insufficient. Besides, talents in western area continuously flow to eastern coastal regions which become the cradle of talent cultivation. Seeing from industrial distribution, as traditional agriculture transforms to modern agriculture, large quantities of agricultural labor force are released to the secondary industry and the tertiary industry. Thus, there is the lack of innovative agricultural talents, which restricts development of ecological green agriculture. The secondary industry and the tertiary industry are the key industries which carry out low carbon economic mode. Innovating energy consumption mode, developing new energy, upgrade industry, energy conservation and effect enhancement put forward new requirements for innovation talents, increase absorbing ability of the secondary industry and the tertiary industry for labor force and relieve employment pressure.

\subsection{Unbalanced talent distribution restricts optimization of human resource allocation}

Unbalanced development of high and new technology industry results in unbalanced flow of high technicians. As shown in Table 3-3, the proportion of high-end talents in developed countries such as Beijing and Shanghai is much higher than that in Sichuan. Among employees in Sichuan, the proportion of junior college graduates, undergraduates and postgraduates is much lower than that in Beijing and Shanghai and national average level. Talents' absorption and transformation ability for knowledge and technology plays a very important role for technical reform, management innovation and new energy development and utilization. Development of low carbon economy depends on innovation. The quantity and quality of innovation talents are the key points of human resource allocation under low carbon economy. In terns of quality of talents, on the one hand, the talents cultivated under current education system have such characteristics as sufficient knowledge reserve and insufficient innovation and knowledge transformation ability. On the other hand, although colleges continuously increase enrollment, the proportion of college students in total population is still lower than that in developed countries. The proportion of the population with bachelor's degree or above in employment population is much lower. In terms of the quantity of talents, China is a large country in the aspect of absolute number of talents. However, China is still short of talents in relative quantity. For western region, human resources needed for development of low carbon economy are insufficient in terms of both quantity and quality. High-end talents flow to developed regions. Western region becomes the base of talent cultivation. This goes against carrying out low carbon economic mode in western region. 
Table 3-1 Total output value of each city and region of Sichuan (2011)

Unit: RMB 100 million

\begin{tabular}{|l|l|l|l|l|l|l|}
\hline \multirow{1}{*}{ City } & & & & & & Per capita \\
\cline { 2 - 6 } & $\begin{array}{c}\text { Regional total } \\
\text { output value }\end{array}$ & $\begin{array}{c}\text { The } \\
\text { primary } \\
\text { industry }\end{array}$ & $\begin{array}{c}\text { The } \\
\text { secondary } \\
\text { industry }\end{array}$ & Industry & $\begin{array}{c}\text { The } \\
\text { tertiary } \\
\text { industry }\end{array}$ & $\begin{array}{c}\text { Total output } \\
\text { value }\end{array}$ \\
\cline { 2 - 6 } $\begin{array}{l}\text { Chengdu } \\
\text { City }\end{array}$ & & & & & & (Yuan) \\
\hline $\begin{array}{l}\text { Zigong } \\
\text { City }\end{array}$ & & & & & & \\
\hline $\begin{array}{l}\text { Luzhou } \\
\text { City }\end{array}$ & & & & & & \\
\hline $\begin{array}{l}\text { Mianyang } \\
\text { City }\end{array}$ & & & & & & \\
\hline Yibin City & & & & & & \\
\hline
\end{tabular}

Data source: 2012 Statistical Yearbook of Sichuan

Table 3-2 Employees of three industries in each city and region of Sichuan

\begin{tabular}{|l|l|l|l|}
\hline \multicolumn{1}{|c|}{ City } & The primary industry & The secondary industry & The tertiary industry \\
\hline Chengdu City & & & \\
\hline Zigong City & & & \\
\hline Luzhou City & & & \\
\hline Mianyang City & & & \\
\hline Yibin City & & & \\
\hline
\end{tabular}

Data source: 2012 Statistical Yearbook of Sichuan

Table 3-3 Education level of nationwide employees

Unit: \%

\begin{tabular}{|c|l|l|l|l|l|l|l|}
\hline Region & Illiteracy & $\begin{array}{c}\text { Primary } \\
\text { school }\end{array}$ & $\begin{array}{c}\text { Middle } \\
\text { school }\end{array}$ & $\begin{array}{c}\text { Senior } \\
\text { high } \\
\text { school }\end{array}$ & $\begin{array}{c}\text { Junior } \\
\text { college }\end{array}$ & $\begin{array}{c}\text { Undergraduate } \\
\text { college }\end{array}$ & Postgraduate \\
\hline Nationwide & & & & & & & \\
\hline Beijing & & & & & & & \\
\hline Shanghai & & & & & & & \\
\hline Sichuan & & & & & & & \\
\hline
\end{tabular}

Data source: 2012 Statistical Yearbook of Chinese Labor Force

\subsection{Failure of human resources market mechanism}

Spontaneous human resource allocation fails to give full play to the best allocation effect due to information asymmetry. On the contrary, internal consumption of human resources happens. Labor market regulatory mechanism fails. This is reflected in supply and demand mechanism and price mechanism of labor market.

Supply and demand mechanism plays a fundamental role in human resource market. Market mechanism adjusts human resource allocation. An ideal state is that human resources are allocated on the correct posts and allocation optimization is realized. However, the realistic situation is that promotion of low carbon economy results in adjustment of industrial structure and energy structure. Post demands change, and human resource demands also alter. Human resource market mechanism fails temporarily in this change, and the adjustment function is lost. Thus, the government needs to guide human resource allocation.

Price mechanism of human resources market is imperfect. Talent market price related to development of low carbon economy cannot reflect value of talents. Price mechanism has good adjustment function for achieving optimization of human resource allocation. Under the mode of market-based pricing, supply-demand relationship is a major factor deciding human resource price. Through government guidance, two-way selection of talents and enterprises achieve rational 
allocation of low-carbon talents. On the one hand, workers are trained, study and improve their abilities according to skills and abilities required by development of low carbon economic mode. On the other hand, enterprises need to take scientific and rational salary system to fully reflect value of talents. To be more specific, stock incentive and profit sharing can be adopted to optimize human resource allocation.

\section{Discussions and countermeasures}

Optimization of human resource allocation can improve important intelligent support for developing low carbon economy. Based on fully investigating development situation of low carbon industry as well as quantity, quality, flow and distribution of human resources, the project group proposes the following thoughts to optimize human resource allocation under low carbon economy, in the hope of proving new thought for achieving low-carbon sustainable development of enterprises and offering reference for formulating guiding policy to carry out low-carbon economic mode.

\subsection{To perfect and develop human resource training system matched with low carbon economy}

It is required to establish, perfect and develop human resource training system matched with low carbon economy. Industrial structure upgrade caused by development of low carbon economy requires macroscopic human resource development must pay high attention to the functions of education and training. Low-carbon development strategy puts forward higher quality requirements for human resources. If enterprises want to achieve energy conservation, emission reduction, effect enhancement, low input and high output, new employment posts should be taken by those with innovation ability who master advanced scientific knowledge and technology. Thus, education training system needs to be established and perfected to meet demand of industrial structure adjustment for human resources. Meanwhile, original industrial structure upgrade and technical equipment transformation also propose higher requirements for human resources. All these need corresponding education and training system. To make human resources satisfy requirements of development of low carbon economic mode in quantity and quality. Competence of human resources can be comprehensively improved through perfecting regular higher education, high vocational education, adult education and internal job skill training of enterprises so as to adapt requirements of low carbon development. Low carbon development needs innovation. So, it is necessary to perfect personnel training system for undergraduates, postgraduates and doctors, optimize innovative personnel training mode of colleges, establish talent prediction index system in three different stages (enrollment, cultivation and employment to better optimize regional human resource allocation. Colleges should optimize specialty setting and personnel training mode in accordance with requirements of development of low carbon economy so as to cultivate a batch of senior experts and innovation teams matched with low carbon economic development, form age structure, level structure and specialty structure of human resources suitable for development of low carbon economy.

\subsection{To optimize human resource allocation in three industries based on low carbon economy}

Unbalanced industrial structure results in unbalanced human resource allocation. Each region should optimize industrial layout according respective advantages, allocate human resources with pertinence and give play to industrial cluster effect and talent accumulation effect.

It is required to improve productive efficiency of the primary industry - agriculture. It is necessary to develop ecological agriculture, enhance superior and characteristic agriculture and agricultural product processing, develop rural ecological tourism, train agricultural technical personnel, enhance absorptive capacity of low-carbon and green agriculture for labor force and expand green employment scale and quality. Meanwhile, more agricultural labor force can be released to the secondary industry and the tertiary industry through boosting capacity of agriculture. The government should work out relevant policies and measures to standardize balanced urban and rural development and guide labor force in the primary industry to transfer to the secondary industry and the tertiary industry orderly. Social security system should be deepened to solve 
worries of rural labor force after transferring to emerging industry. As well, skill training for workers in the emerging industry should be intensified to meet upgrade and update of energy conservation, emission reduction and effect enhancement of the secondary industry. It is also necessary to actively guide the secondary industry for energy conservation and effect enhancement, transfer to environmentally-friendly development mode and increase absorptive capacity of labor employment. In addition, it is also necessary to strive to develop energy conservation transformation of the tertiary industry (especially construction industry, wholesale and retail as well as transportation industry with high contribution rate), enhance digestive ability of the tertiary industry for employment and relieve employment pressure.

\subsection{To activate market mechanism and fulfill optimization of human resource allocation}

To activate labor market mechanism is to make value law give play to regulating effect of human resource allocation under low carbon economic mode, ensure timely supply of human resource in low-carbon industrial structure adjustment and meanwhile flexibly release human resources in labor market. Market forces should play a role in supply and demand mechanism, competitive mechanism and price mechanism and realize optimization of human resource allocation. Specific measures include the following:

1. Supply and demand mechanism. Under low carbon economic mode, on the one hand, it is required to keep total balance of human resource supply and demand. On the other hand, it is necessary to predict and monitor supply-demand situations of low carbon human resources market and facilitate dynamic balance of supply-demand relationship through macro-policy guidance.

2. Competitive mechanism. Development of low carbon economy makes industrial structure alter. As enterprises' technical equipment level improves, new requirements for laborers' ability and skills are proposed. Laborers' employment competition and work competitions intensify. This makes laborers continuously improve their competition ability through learning and training. Meanwhile, under low carbon development strategy, inter-enterprise competitions are mostly reflected in science and technology competition, while the key of science and technology competition is talent competition. So, many enterprises attract excellent personnel through high salary and good working environment.

3. Price mechanism. On the one hand, it is required to standardize evaluation mechanism of human resources, identity talents and achieve maximization of talent allocation. On the other hand, talent incentive and evaluation mechanism should be established and perfected. Human resource evaluation is the basis of identifying talents and fully utilizing talents. It is necessary to establish all-round talent incentive mechanism, fully mobilize talents' enthusiasm and fulfill strategic target of low carbon development.

Of course, human resource market can complete circular movement under joint effect of supply and demand mechanism, competitive mechanism and price mechanism, and achieve rational allocation of human resources.

\subsection{To perfect government's employment policy and guide optimization of human resource allocation}

Increase government's capital input. In the initial stage of development of low carbon economy, high cost input is needed for promotion of low carbon employment. Since there is large market risk, the government should serve as a model. The government should offer financial aid and support in terms of industrial planning and financial policy. The government can take reduction or remission of taxes, soft loan and subsidy to increase support force for employment post cultivation of low carbon industry.

Perfect the laws and regulations and make low carbon employment have laws to abide by. At present, in the aspect of development of low carbon economic mode, most documents are government administration rules and guidance documents. There is no mature law to abide by. The policy of encouraging low carbon employment not just lacks systematicness, but also lacks feasible implementation strategy in operation. To achieve human resource allocation optimization under low carbon economic mode, it is imperative to formulate perfect legal system. On the one hand, the government should establish and perfect legal system about employment matched with low carbon 
development, replace planning and suggestion with legislation and make low carbon employment have laws to abide by. On the other hand, under the total framework of development of low carbon economic strategy, specific and feasible implementation strategies should be issued to drive low carbon employment. It is necessary to make human resources really become intelligent support of achieving low-carbon economic development strategy through legislation and administrative means.

In conclusion, development of low carbon economic mode results in industrial structure adjustment, which will inevitably trigger new employment structure change. Low carbon economic mode drives employment. This indicates low carbon development is not just an idea, but also an economic strategy of achieving sustainable development. Low carbon development promotes continuous technical innovation and optimization of energy structure. It will certainly become a new economic growth point. Meanwhile, it can bring new hope for relieving current employment pressure. Of course, transformation to low carbon employment needs certain cost. We should be based on actual situations of economic development, tale actions, actively promote optimization of human resource allocation and provide intelligent support for low carbon development.

\section{Acknowledgments}

This paper contains the phased results of scientific research fund project of Sichuan University of Science \& Engineering, with the title of study on human resource allocation under low carbon economic mode. (Project No.: 2009XJKPW001)

\section{References}

[1] Energy Information Administration. International EnergyOutlook 2006 [R]. US :Official Energy Statistics , 2006

[2]IPCC.Summary for Policymakers of Climate Change 2007:Mitigation. Contribution of Working Group III to the FourthAssessment Report of the Intergovernmental Panel on Climate Change [M]. UK: Cambridge University Press, 2007.

[3] Zigong Municipal People's Government. 2012 energy conservation work report of Zigong City

[4] Feng Ying, Ji Hengkuan, Green New Deal and Green Employment [J]. Impact of Science on Society, 2010(2) 